\title{
Mikrocytos roughleyi taxonomic affiliation leads to the genus Bonamia (Haplosporidia)
}

\author{
N. Cochennec-Laureau ${ }^{1,4, *}$, K. S. Reece $^{2}$, F. C. J. Berthe ${ }^{1}$, P. M. Hine ${ }^{3}$ \\ ${ }^{1}$ Institut Français de Recherche pour l'Exploitation de la Mer (IFREMER), Laboratoire de Génétique et Pathologie, \\ PO Box 1346, 17390 La Tremblade, France \\ ${ }^{2}$ Virginia Institute of Marine Science (VIMS), Aquaculture Genetics and Breeding Technology Center, Gloucester Point, \\ Virginia 23062, USA \\ ${ }^{3}$ Aquatic Animal Diseases, National Centre for Disease Investigation, Ministry of Agriculture and Fisheries (MAF) \\ Operations, PO Box 40-742, Upper Hutt, 6007 Wellington, New Zealand \\ ${ }^{4}$ Present address: IFREMER, Laboratoire d'Aquaculture Tropicale, BP 7004, 98719 Taravao, French Polynesia
}

\begin{abstract}
Microcell-type parasites of oysters are associated with a complex of diseases in different oyster species around the world. The etiological agents are protists of very small size that are very difficult to characterize taxonomically. Associated lesions may vary according to the host species, and their occurrence may be related to variations in tissue structure. Lesion morphology cannot be used to distinguish the different agents involved. Ultrastructural observations on Mikrocytos roughleyi revealed similarities with Bonamia spp., particularly in regard to the presence of electron-dense haplosporosomes and mitochondria, whose absence from $M$. mackini also indicate that M. roughleyi and M. mackini are not congeneric. A partial small subunit (ssu) rRNA gene sequence of M. roughleyi was determined. This partial sequence, 951 nucleotides in length, has 95.2 and $98.4 \%$ sequence similarities with $B$. ostreae and $B$. exitiosus ssu rDNA sequences, respectively. Polymorphisms among the ssu rDNA sequences of $B$. ostreae, $B$. exitiosus and $M$. roughleyi allowed identification of restriction enzyme digestion patterns diagnostic for each species. Phylogenetic analysis based on the ssu rDNA data suggested that $M$. roughleyi belongs in the phylum Haplosporidia and that it is closely related to Bonamia spp. On the basis of ultrastructural and molecular considerations, $M$. roughleyi should be considered a putative member of the genus Bonamia.
\end{abstract}

KEY WORDS: Mikrocytos roughleyi · Saccostrea glomerata · Bonamiosis · Microcell · Taxonomy · Small subunit rDNA

Resale or republication not permitted without written consent of the publisher

\section{INTRODUCTION}

Among the 10 OIE (Office International des Epizooties: the World Organization for Animal Health)listed diseases of molluscs, 4 are caused by non-sporeforming organisms given the collective name of 'microcell' (Farley et al. 1988). Of these, 1 disease, bonamiosis, is caused by at least 2 haplosporidian protozoans that infect the haemocytes of flat oysters. Bonamia ostreae infects the European flat oyster Ostrea edulis in Europe and in North America (Pichot et al.
1980, Bannister \& Key 1982, Polanco et al. 1984, Elston et al. 1986, McArdle et al. 1991, Barber \& Davis 1994), $B$. exitiosus infects the New Zealand dredge oyster $T$. chilensis (Dinamani et al. 1987, Hine 1991, Hine et al. 2001b), and Bonamia-like organisms also infect the flat oysters O. angasi in Australia (Hine 1996) and T. chilensis in Chile (Kern 1993, Campalans et al. 2000) (present Table 1). A second disease, mikrocytosis, is caused by 2 other 'microcell' protozoans: Mikrocytos mackini causes Denman Island disease in the Pacific oysters Crassostrea gigas in British Columbia (Quayle 1961, 
Table 1. Comparisons among pathogen species, natural and experimental hosts, gross signs, histological features and parasite location. nd: disease experimental reproduction not done

\begin{tabular}{|c|c|c|c|c|c|}
\hline & Bonamia ostreae & Bonamia exitiosus & Bonamia sp. & Mikrocytos roughleyi & M. mackini \\
\hline Natural hosts & Ostrea edulis & Tiostrea chilensis & $\begin{array}{l}\text { O. angasi } \\
\text { T. chilensis }\end{array}$ & Saccostrea glomerata & Crassostrea gigas \\
\hline Experimental hosts & $\begin{array}{l}\text { O. puelchana } \\
\text { O. concaphila } \\
\text { O. angasi } \\
\text { T. chilensis } \\
\text { C. rivularis }\end{array}$ & nd & nd & nd & $\begin{array}{l}\text { C. virginica } \\
\text { O. edulis } \\
\text { O. concaphila }\end{array}$ \\
\hline Gross signs & $\begin{array}{l}\text { Gill and mantle } \\
\text { perforations or } \\
\text { indentations }\end{array}$ & No sign & No sign & $\begin{array}{l}\text { Abscesses and } \\
\text { pustules on mantle } \\
\text { or muscle }\end{array}$ & $\begin{array}{l}\text { Abscesses and } \\
\text { pustules on mantle } \\
\text { or muscle }\end{array}$ \\
\hline Histological features & $\begin{array}{l}\text { Global haemocyte } \\
\text { infiltration }\end{array}$ & $\begin{array}{l}\text { Global haemocyte } \\
\text { infiltration }\end{array}$ & $\begin{array}{l}\text { Global haemocyte } \\
\text { infiltration }\end{array}$ & $\begin{array}{l}\text { Focal haemocyte } \\
\text { infiltration }\end{array}$ & $\begin{array}{l}\text { Focal haemocyte } \\
\text { infiltration }\end{array}$ \\
\hline Location & $\begin{array}{l}\text { Haemocytes and } \\
\text { cells epithelial }\end{array}$ & Haemocytes & Haemocytes & Haemocytes & $\begin{array}{l}\text { Haemocytes, } \\
\text { myocytes, } \\
\text { connective cells }\end{array}$ \\
\hline
\end{tabular}

Farley et al. 1988), and M. roughleyi causes winter mortality in the Sydney rock oyster Saccostrea glomerata in SE Australia (Roughley 1926, Farley et al. 1988). Experimentally, Bonamia spp. can infect Ostrea spp. (Grizel et al. 1983, Le Borgne \& Le Pennec 1983, Bougrier et al. 1986, Pascual et al. 1991) and C. rivularis (Cochennec et al. 1998). M. mackini has been shown to infect C. gigas, C. virginica, O. edulis and O. concaphila (Bower et al. 1997) (present Table 1). Therefore, Bonamia spp. and Mikrocytos spp. cannot be distinguished solely by the hosts which they infect. However, to date the geographic distributions of the 2 Mikrocytos species appear to be distinct, with $M$. mackini having been reported only in western Canada and $M$. roughleyi only in eastern Australia.

Several studies have included observations of the ultrastructure of Bonamia ostreae (Comps et al. 1980, Pichot et al. 1980, Bréhelin et al. 1982, Grizel et al. 1983, Grizel 1985, Chagot et al. 1992, Montes et al. 1994) and B. exitiosus (Dinamani et al. 1987, Hine 1991, Hine \& Wesney 1994a,b, Hine et al. 2001b), but there are none on Bonamia sp. in Ostrea angasi in Australia or Tiostrea chilensis in Chile. A recent study on the ssu rDNA gene sequences of $B$. ostreae (Carnegie et al. 2000, Cochennec et al. 2000) and Bonamia sp. from New Zealand showed that they are congeneric, and a new species, B. exitiosus, was created (Hine et al. 2001b). An unpublished study on the ssu rDNA gene sequences of Bonamia sp. from Australia and $B$. exitiosus from New Zealand suggests that these 2 parasites are conspecific, despite showing very different pathology in their respective hosts (R. D. Adlard pers. comm.).

The ultrastructure of Mikrocytos mackini confirms that this parasite is different from Bonamia spp. because of the lack of organelles in most eukaryotic cells including mitochondria or their equivalents (Farley et al. 1988, Hine et al. 2001a). There have been no published studies on the ultrastructure of $M$. roughleyi. The only Mikrocytos sp. for which sequences from the ssu rDNA gene cluster have been published is $M$. roughleyi (Adlard \& Lester 1995).

Certification of stocks as free from specific disease agents prior to movement is the basis of disease control in member countries of the Office International des Epizootis. For this to be effective, listed etiological agents must be reliably detectable and identifiable. Heavy infection by microcells may be detected by light microscopy, but identification cannot be carried out with any certainty. Also, light infection cannot reliably be detected by light or electron microscopy. There is an urgent need to characterize each 'microcell' species, and identify gene sequences that allow them to be distinguished from each other.

The aim of this study was the characterization of Mikrocytos roughleyi by means of ultrastructural observation and ssu rDNA gene sequence determination to clarify taxonomic relationships with other microcell parasites.

\section{MATERIALS AND METHODS}

Electron microscopy. $4 \%$ glutaraldehyde (in $0.2 \mathrm{M}$ cacodylate buffer) fixed tissues from infected Saccostrea glomerata were provided by R. Hand, New South Wales Australia Fisheries Department. They were post-fixed for $1 \mathrm{~h}$ in $1 \%$ osmium tetroxide $\left(\mathrm{OsO}_{4}\right)$ in $0.2 \mathrm{M}$ cacodylate buffer. Tissues were then cleared in propylene oxide and embedded in epon resin. Ultra- 
thin sections were made using copper grids and double-stained with uranyl acetate and lead citrate. These were then examined in a Jeol JEM 1200 EX transmission electron microscope.

DNA extraction. Genomic DNA was extracted from ethanol-fixed, individually infected oysters. Tissues were suspended in 10 volumes of extraction buffer ( NaCl 100 mM, EDTA 25 mM, pH 8, SDS 0.5\%) with Proteinase K $\left(100 \mu \mathrm{g} \mathrm{ml}^{-1}\right)$. Following overnight incubation at $50^{\circ} \mathrm{C}$, DNA was extracted using a standard phenol/chloroform protocol followed by ethanol precipitation (Sambrook et al. 1989).

Polymerase chain reaction. The partial ssu rDNA was amplified using the universal primer Suni and the Bonamia ostreae specific primer Bo-Boas (Cochennec et al. 2000). PCR was performed in $50 \mu \mathrm{l}$ volume containing about $10 \mathrm{ng}$ of DNA with $5 \mu \mathrm{l}$ of $10 \times$ PCR buffer, $5 \mu \mathrm{l}$ of $25 \mathrm{mM} \mathrm{MgCl}_{2}, 5 \mu \mathrm{l}$ of $2 \mathrm{mM}$ dNTP, $0.5 \mu \mathrm{l}$ of each $100 \mu \mathrm{M}$ primer and $0.25 \mu \mathrm{l}(1 \mathrm{U})$ of Taq DNA polymerase (Promega). Samples were denatured for 5 min at $94^{\circ} \mathrm{C}$ and amplified by 30 cycles: 1 min at $94^{\circ} \mathrm{C}$ for denaturation, $1 \mathrm{~min}$ at $55^{\circ} \mathrm{C}$ for primer annealing, and $1 \mathrm{~min}$ at $72^{\circ} \mathrm{C}$ for elongation in a thermal cycle apparatus (Appligene). Polymerization at $72^{\circ} \mathrm{C}$ was extended for $10 \mathrm{~min}$ to ensure complete elongation of the amplified products. After amplification, $5 \mu \mathrm{l}$ of the PCR products were analyzed by electrophoresis on ethidium bromide-staining agarose gel $(2 \%$ in Tris acetate EDTA buffer).

DNA sequencing. Amplicons (= PCR products) were cloned using the TA Cloning kit (Invitrogen) following the manufacturer's protocol. Two recombinant plasmids with putative ssu rDNA inserts were sequenced by Appligene (Laboratory Qbiogen). Sequences were compared for similarity with public databases lodged in GenBank and EMBL using BLAST (Altschul et al. 1990).

Restriction fragment length polymorphism (RFLP). A PCR was performed with primers designed for amplification of Bonamia ostreae: Bo-Boas (Cochennec et al. 2000). Template DNA was obtained from Mikrocytos roughleyi, infected Saccostrea glomerata, B. exitiosus-infected Tiostrea chilensis and B. ostreae, infected Ostrea edulis. RFLP analysis was performed by separate digestions of $10 \mu \mathrm{l}$ of PCR product with BglI and HaeII (Promega, France). The resulting fragment patterns were analyzed electrophoretically on $2 \%$ agarose gel.

Phylogenetic analysis. Phylogenetic analyses were conducted by aligning the Mikrocytos roughleyi ssu rDNA sequence with 53 other protistan ssu rDNA sequences, including those of dinoflagellates (Amphidinium carterae: AF009217; Pfiesteria piscicida: AF077055; Prorocentrum minimum: Y16238; Alexandrium fundyense: U09048; Gonyaulax spinifera:
AF052190; Symbiodinium corculorum: L13717); apicomplexans (Babesia bovis: L19078; Theileria parva: L02366; Eimeria tenella: U40264; Sarcocystis hominis: AF006470; Toxoplasma gondii: U03070); ciliates (Euplotes crassus: AY007438; Oxytricha nova: X03948; O. trifallax: AF164121; Entodinium caudatum: U57765; Paramecium tetraurelia: X03772; Tetrahymena pyriformis: M98021; T. thermophila: X56165); fungi (Ajellomyces capsulatus: Z75307; Neurospora crassa: X04971. Kluyveromyces lactis: X51830; Saccharomyces cerevisiae: J01353; Candida glabrata, X51831; Pneumocystis carinii: S83267); stramenopiles (Fucus distichus: M97959; Ochromonas danica: M32704; Achlya bisexualis: M32705; Phytophthora megasperma: X54265; QPX; AF261664; Ulkenia profunda: L34054); haplosporidians (Bonamia ostreae: AF192759; B. exitiosus: AF337563; Minchinia teredinis: U20319; Haplosporidium nelsoni: U19538; H. costale: AF387122; H. louisiana: U47851; Urosporidium crescens: U47852); Perkinsus spp. (P. marinus: AF042708; P. atlanticus: AF140295; P. chesapeaki: AF042707); and other protozoans (Emiliania huxleyi: M87327; Chlamydomonas reinhardtii: M32703; Nitella flexilis: U05261; Acanthamoeba palestinensis: L09599; Dictyostelium discoideum: X00134; Naegleria fowleri: U80059; Physarum polycephalum: X13160; Trypanosoma cruzi: X53917; Euglena gracilis: M12677; Encephalitozoon cuniculi: L17072; Chondrus crispus: Z14140; Vairimorpha necatrix: Y00266; Giardia lamblia: M54878). The sequences were aligned using the CLUSTAL-W algorithm (Thompson et al. 1994) in the MacVector 7.0 DNA sequence analysis software package (Oxford Molecular) with gap penalties of 8 for gap insertions and 3 for gap extensions in both pairwise and multiple alignment phases. Parsimony jack-knife analysis was performed using PAUP*4b10.0 (Swofford 2002) with 100 random additions of 100 jack-knife replicates.

\section{RESULTS}

\section{Ultrastructural studies}

Mikrocytos roughleyi cells were found in haemocytes within the gills and digestive gland. Infected haemocytes generally contained several parasites. The structure of some haemocytes was only slightly affected, while others were more profoundly altered and displayed vacuolization (Fig. 1). The simplest form of the parasite was ovoid, about 3 to $5 \mu \mathrm{m}$ in diameter, and bound by a unit membrane. The nuclear envelope consisted of an inner and an outer membrane. A peripherally located nucleolus was sometimes present. The cytoplasm was densely packed with ribosomes and contained 1 or 2 mitochondrial profiles in section. 
In addition, 1 to 11 haplosporosomes, displaying an electron-dense matrix, were observed (Fig. 2). Single cytoplasmic lipid droplets were rarely observed. Plasmodial forms with 2 to 4 nuclei were rarely observed (Figs. $3 \& 4$ ). These cells were larger and their nuclei and cellular shapes were more irregular than the uninucleate cells. They had cytoplasmic haplosporosomes, as did the smaller cells, but more numerous mitochondria. Small strands of smooth endoplasmic reticulum were sometimes observed.
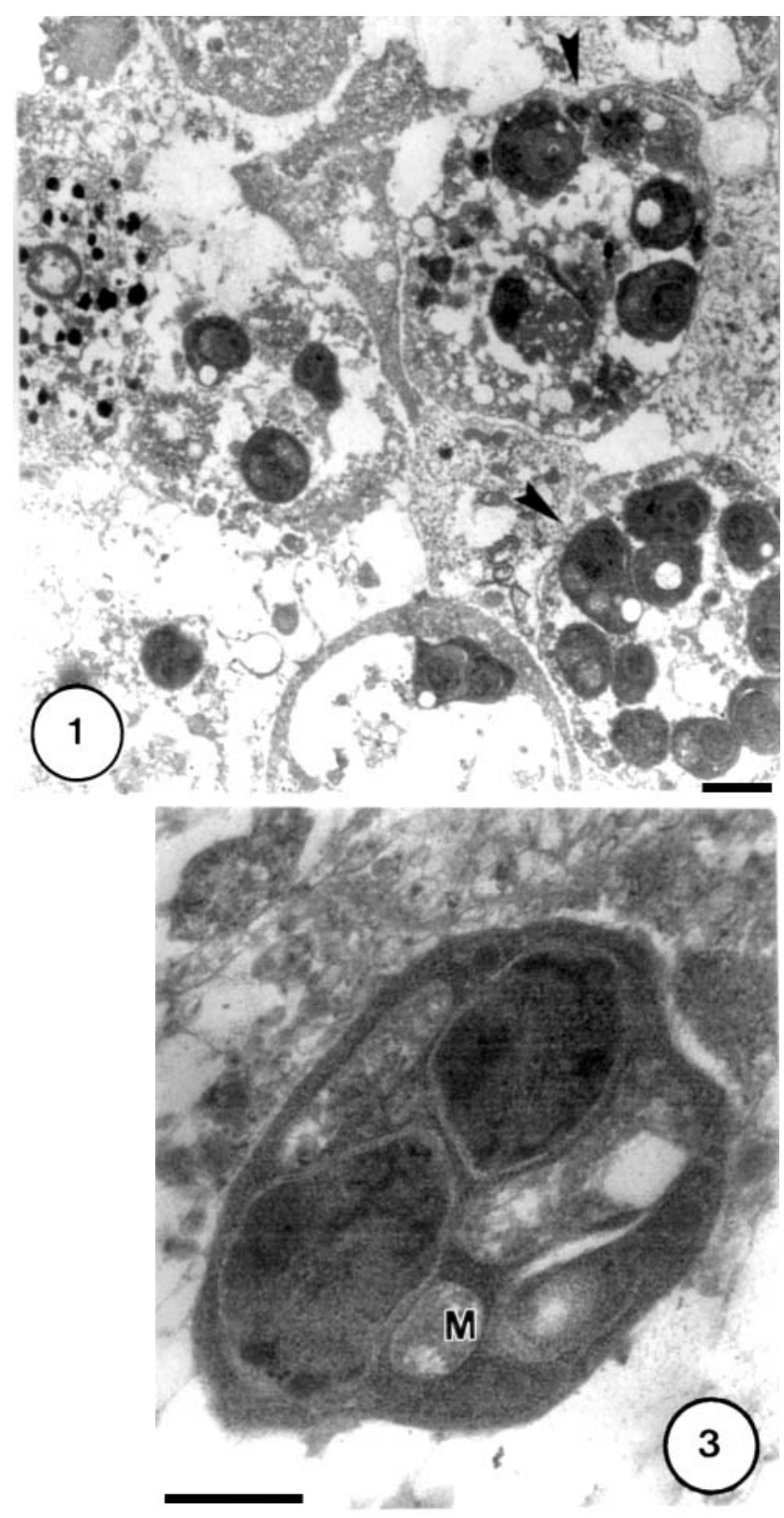

\section{DNA sequence}

An amplicon of 951 bp was obtained. (GenBank Accession No. $=$ AF508801). BLAST analysis of this sequence against public databases confirmed that it is an ssu rRNA gene sequence and revealed similarities with ssu rRNA gene sequences of taxa in the phylum Haplosporidia, particularly with those in the genus Bonamia. B. ostreae and B. exitiosus sequence similarities were 95.2 and $98.4 \%$, respectively.

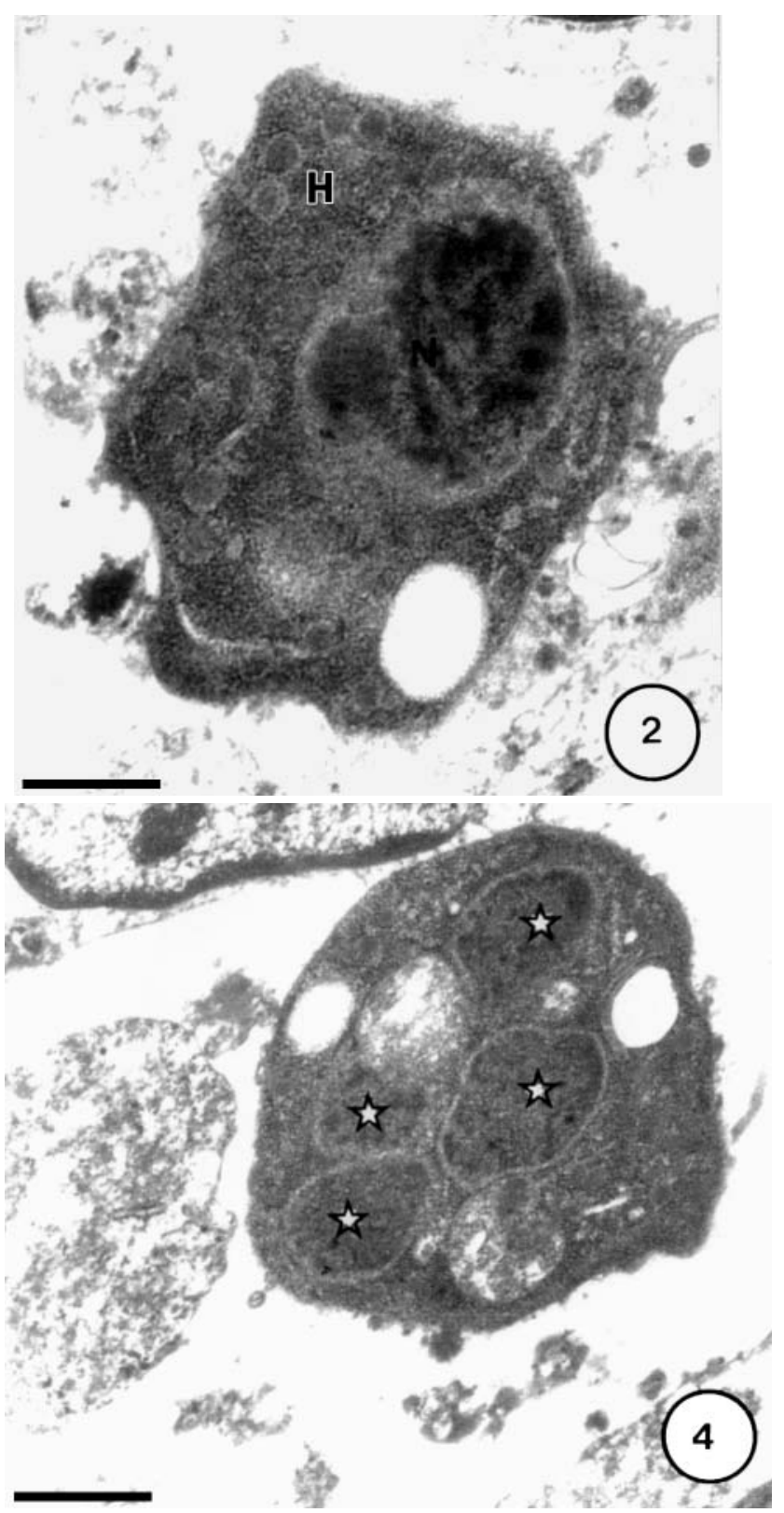

Figs. 1 to 4. Saccostrea glomerata naturally infected with Mikrocytos roughleyi. Electron microscopy. Fig. 1. Infected oyster showing numerous parasites within hemocyte cytoplasm (arrow) (scale bar $=3 \mu \mathrm{m}$ ). Fig. 2. Parasite showing nucleus with excentric nucleolus $(\mathrm{N})$, electron-dense haplosporosomes $(\mathrm{H})(\mathrm{scale}$ bar $=200 \mathrm{~nm})$. Fig. 3. Diplokaryotic cell showing mitochondria $(\mathrm{m})(\mathrm{scale}$ bar $=200 \mathrm{~nm})$. Fig. 4. Multinucleate plasmodial stage with 4 nuclei (stars) (scale bar $=500 \mathrm{~nm})$ 


\section{B.exitiosus M.roughleyi B.ostreae}

B.exitiosus M.roughleyi B.ostreae

\section{B.exitiosus M.roughleyi B.ostreae}

\section{B.exitiosus M.roughleyi B.ostreae}

\section{B.exitiosus M.roughleyi B.ostreae}

$\begin{array}{ll}\text { B.exitiosus } & \text { ATCAG } \\ \text { M.roughleyi } & \text { ATCAG } \\ \text { B.ostreae } & \text { ATCAG }\end{array}$

Fig. 5. Bonamia ostreae, B. exitiosus and Mikrocytos roughleyi Bo-Boas sequence alignment (CLUSTALW). Positions of recognition sites of restriction enzymes BglI and HaeII indicated by arrowheads
CCATTTAATTGGTCGGGCCGCTGGTCCTGATCCTTTACTTTGAGAAAATTAAAGTGCTCA
CCATTTAATTGGTCGGGCCGCTGGTCCTGATCCTTTACTTTGAGAAAATTAAAGTGCTCA
CCATTTAATTGGTCGGGCCGCTGGTCCTGATCCTTTACTTTGAGAAAATTAAAGTGCTCA

$\mathbf{y}$

AAGCAGGCTCGCGCCTGAATGCATTAGCATGGAATAATAAGACACGACTTCGGCGCCGCC AAGCAGGCTCGCGCCTGAATGCATTAGCATGGAATAATAAGACACGACTTCGGCACCGCC AAGCAGGCTCGCGCCTGAATGCATTAGCATGGAATAATAAGACACGACTTCGGCGCCGCC

\author{
ACTCGTGGCGGGTGTTTTGTTGGTTTTGAGCTGGAGTAATGATTGATAGAAACAATTGGG \\ ACTCGTGGCGGGTGTTTTGTTGGTTTTGAGCTGGAGTAATGATTGATAGAAACAATTGGG \\ ...- TC---GGCGGTTGTTTTGTTGGTTTTGAGCTGGAGTAATGATTGATAGAAACAATTGGG \\ A BglI
}

GGTGCTAGTATCGCCGGGCCAGAGGTAAAATTCTTTAATTCCGGTGAGACTAACTTATGC GGTGCTAGTATCGCCGGGCCAGAGGTAAAATTCTTTAATTCCGGTGAGACTAACTTATGC GGTGCTAGTATCGCCGGGCCAGAGGTAAAATTCTTTAATTCCGGTGAGACTAACTTATGC

\begin{abstract}
GAAAGCATTCACCAAGCGTGTTTTCTTTAATCAAGAACTAAAGTTGGGGGATCGAAGACG GGAAGCATTCACCAAGCGTGTTTTCTTTAATCAAGAACTAAAGTTGGGGGATCGAAGACG GAAAGCATTCACCAAGCGTGTTTTCTTTAATCAAGAACTAAAGTTGGGGGATCGAAGACG
\end{abstract}

Assessment of ssu rDNA polymorphism

CLUSTAL-W multiple alignment program showed a polymorphic region of 6 base pairs. This region was located within the specific Bonamia genus Bo-Boas primer amplified sequence (Fig. 5). Results of RFLP analysis of $B$. ostreae, B. exitiosus and Mikrocytos roughleyi PCR products are given in Fig. 6. The $B$. ostreae profile consisted of 2 bands (120 and $180 \mathrm{pb}$ ) for $B g l$ I and 2 bands (115 and 185 pb) for Hae II, while the $B$. exitiosus profile consisted of 1 band (304 pb) and 2 bands (117 and $187 \mathrm{pb})$, respectively. The $M$. roughleyi profile consisted of a unique band (304 pb) for both Bgl I and Hae II.

\section{Phylogenetic analysis}

Phylogenetic relationships of Mikrocytos roughleyi were inferred by parsimony analysis of ssu rDNA sequences from $M$. roughleyi and 53 other eukaryotic taxa. The $M$. roughleyi sequence grouped with the sequences for taxa in the phylum Haplosporidia, particularly with the sequences from Bonamia ostreae and

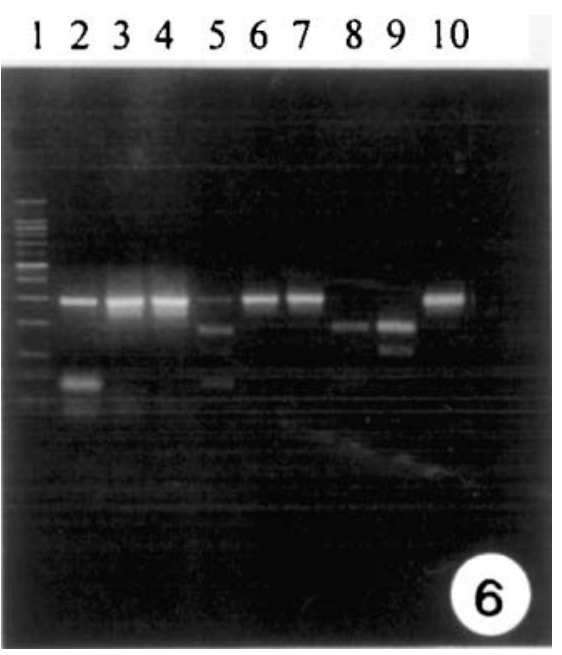

Fig. 6. Two \% agarose gel electrophoresis. Lane 1: 100 bp molecular weight marker. Lanes 2 to 4: specific Bonamia genus PCR; Lane 2: 300 bp product obtained with $B$. ostreae DNA; Lane 3: 304 bp product obtained with $B$. exitiosus DNA; Lane 4: 304 bp product obtained with Mikrocytos roughleyi DNA; Lanes 5 to 10: RFLP results; Lanes 5 and 8: $B$. ostreae profile showing 2 bands both for BglI and Hae II; Lanes 6 and 9: B. exitiosus profile showing 1 band for BglI and 2 bands for Hae II; Lanes 7 and 10: M. roughleyi profile showing 1 band for both BglI and Hae II 
B. exitiosus. The bootstrap support value for grouping B. exitiosus with $M$. roughleyi was 69 and $100 \%$ for the B. ostreae/B. exitiosus/M. roughleyi clade (Fig. 7). This clade is found nested within the Haplosporidia, which is monophyletic with a support value of $100 \%$.

\section{DISCUSSION}

The taxonomy of Bonamia spp. and Mikrocytos spp. remains unclear, and their relationships with other protistans are poorly understood. Initially, M. roughleyi was considered to be a distinct genus from Bonamia on the basis of gross signs of the diseases each causes, associated histological lesions and host species affected (Farley et al. 1988). There is some evidence that gross signs and lesions depend on the species of host, rather than the species of parasite. B. exitiosus in Tiostrea chilensis in New Zealand closely resembles Bonamia sp. in Ostrea angasi in Australia, and they may be conspecific. B. exitiosus only infects haemocytes, does not cause gill lesions, and heavy

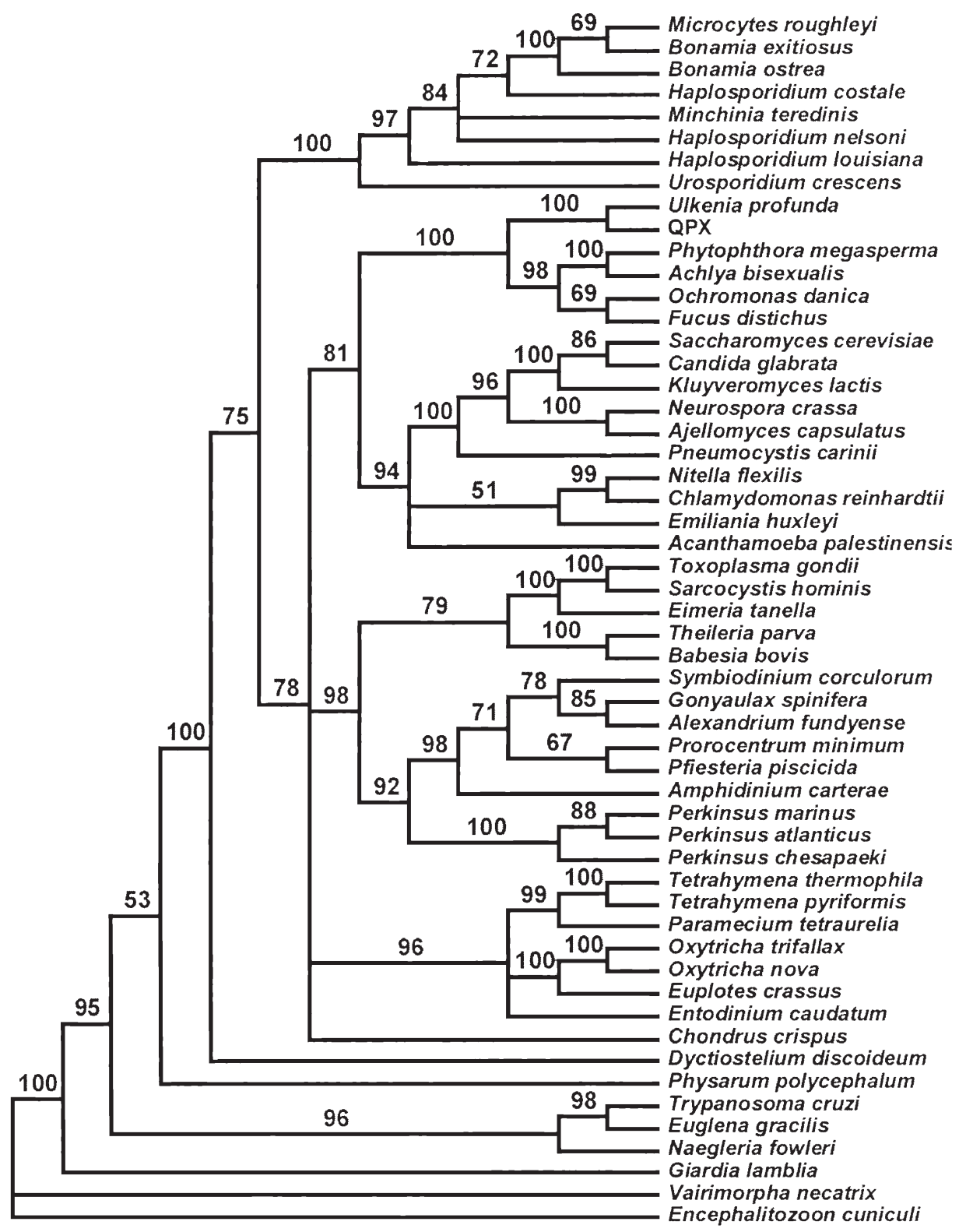

Fig. 7. Parsimony bootstrap consensus tree generated by phylogenetic analysis of the Mikrocytos roughleyi ssu rDNA sequence with 53 other representative, taxonomically diverse, eukaryote ssurDNA sequences. Bootstrap support values above 50 are shown on branches. Analysis was done with 100 bootstrap replicates of 100 random additions and gaps were treated as missing data 
parasite burdens are associated with this disease. Australian Bonamia sp. infects gill epithelial cells and haemocytes, causes gill lesions, and a relatively small number of these parasites are capable of causing severe disease. B. ostreae is intermediate in that it infects both haemocytes and epithelial cells, it causes gill lesions, but only heavy parasite burdens are associated with disease (Comps et al. 1980, Pichot et al. 1980, Balouet et al. 1983, Montes et al. 1994). Absence of gill lesions in B. exitiosus-infected T. chilensis may be due to lack of infection of gill epithelium or to the greater collagen content of $T$. chilensis gills compared to other Tiostrea species; this in turn may be related to the long larval brooding period of $3 \mathrm{wk}$ between the gills (Hine 1991, Hine \& Wesney 1994a,b).

Ultrastructural studies showed that Mikrocytos roughleyi presents more similarities to Bonamia ostreae and $B$. exitiosus than to its congener $M$. mackini. Particularly notable are the presence of haplosporosomes and mitochondria in Bonamia spp. and $M$. roughleyi, and their absence from $M$. mackini (Hine et al. 2001a). Diplokaryotic plasmodia were rare in this study, but tetra-nucleate plasmodia were observed similar to those described in B. ostreae and B. exitiosus (Brehélin et al. 1982, Hine et al. 2001b). The large multinucleate stage that occurs in Haplosporidium spp. and Minchinia spp., and the characteristic spores of those genera, were not observed.

The lack of concordance between genotypic and phenotypic traits herein is not confined to haplosporidians and does not always mean that apparently ultrastructurally diverse species may be congeneric. Microsporidian parasites of the genus Pleistophora spp. appear ultrastructurally to be closely related, although they infect insects and fishes. However, rDNA sequencing has shown that the Pleistophora spp. infecting fishes are polyphyletic, and that Pleistophora spp. in insects are not related to the species in fishes (Nilsen et al. 1998). Ultrastructural characters considered important in microsporidian classification appear to have arisen several times during evolution. Similarly, the haplosporosomes and haplosporosome-like bodies that originally characterized ascetosporans only are now known to occur in paramyxeans and vegetative stages of a primitive clade of myxozoans (Anderson et al. 1999), and cannot be considered as characteristic of haplosporidians only.

The preliminary ultrastructural description provided here was not sufficient to elucidate relationships of Mikrocytos roughleyi with Bonamia spp. Therefore, the ssu rDNA gene was sequenced. This gene has been widely used in the taxonomic study of oyster pathogens including $B$. ostreae and $B$. exitiosus and Haplosporidium spp. (Fong et al. 1993, Ko et al. 1995, Stokes et al. 1995, Flores et al. 1996, Carnegie et al.
2000, Cochennec et al. 2000, Hine et al. 2001a). Adlard \& Lester (1995) proposed a $M$. roughleyi-diagnostic method based on amplification of a segment of the internal transcribed spacer region (ITS) within the ribosomal gene cluster (rRNA). However, attempts to sequence the gene were unsuccessful. The ssu rDNA sequence of $M$. roughleyi obtained in this study showed strong similarity to those of $B$. ostreae and $B$. exitiosus, and also to $H$. nelsoni, $H$. costale and $M$. teredinis, suggesting that $M$. roughleyi shares homologies with the phylum Haplosporidia. These results confirm earlier studies indicating that Bonamia spp. are related to the genus Haplosporidium (Carnegie et al. 2000, Cochennec et al. 2000). In addition, some divergent regions among the Bonamia spp. and $M$. roughleyi were evident. This polymorphism was confirmed by RFLP analysis, and allowed a rapid molecular assay for the discrimination of these 3 parasites.

This additional genomic information, combined with that on Bonamia ostreae and B. exitiosus, suggests that Bonamia and Mikrocytos roughleyi should be included in the phylum Haplosporidia. Such results indicate the difficulty in explaining phenotypic features, including the lack of a known spore stage in Bonamia spp. and the presence of a vacuolated stage in $B$. exitiosus (Hine et al. 2001b), but its apparent lack in B. ostreae and Haplosporidium spp. Therefore, it is important to carry out further ultrastructural and genetic studies. Particularly, there is a need to complete the ssu rDNA sequence to eliminate possible analysis artefacts. Sequencing of other genes of phylogenetic interest will test our hypothesis (Baldauf et al. 2000). Such work, using 2 approaches, is essential as a first step towards elucidation of microcell relationships and taxonomy, and one of the benefits of such studies will be the development of specific identification tools for each parasite species.

In conclusion, based on our ultrastructural and molecular results, we propose a revision of Mikrocytos rougheyi taxonomy, and that $M$. roughleyi be considered as a putative member of the phylum Haplosporidia. More molecular or ultrastructural data are needed to confidently determine whether $M$. roughleyi should be placed in the genus Bonamia.

Acknowledgements. The authors thank Ros Hand from the New South Wales Fisheries Department for providing Mikrocytos roughleyi-infected Saccostrea glomerata. The authors also acknowledge Noelia Carrasco for technical assistance.

\section{LITERATURE CITED}

Adlard RD, Lester RJG (1995) Development of a diagnostic test for Mikrocytos roughleyi, the aetiological agent of Australian winter mortality of the commercial rock oyster, 
Saccostrea commercialis (lredale \& Roughley). J Fish Dis 18:609-614

Altschul SF, Gish W, Miller W, Myers EW, Lipman DJ (1990) Basic local alignment search tool. J Mol Biol 215:403-410

Anderson CL, Canning EU, Okamura B (1999) Molecular data implicate bryozoans as hosts for PKX (phylum Myxozoa) and identify a clade of bryozoan parasites within the Myxozoa. Parasitology 119:555-561

Baldauf SL, Roger AJ, Wenk-Siefert I, Doolittle WF (2000) A kingdom-level phylogeny of eukaryotes based on combined protein data. Science 290:972-977

Balouet G, Poder M, Cahour A (1983) Haemocytic parasitosis: morphology and pathology of lesions in the French flat oyster, Ostrea edulis L. Aquaculture 34:1-14

Bannister C, Key D (1982) Bonamia, a new threat to the native oyster fishery. Fishes Notes. Ministry of Agriculture, Fisheries and Food Directorate, Lowestoft

Barber BJ, Davis C (1994) Prevalence of Bonamia ostreae in Ostrea edulis populations in Maine. J Shellfish Res 13: 298-302

Bougrier S, Tigé G, Bachère E, Grizel H (1986) Ostrea angasi acclimatization to French coasts. Aquaculture 58:151-154

Bower SM, Hervio D, Meyer GR (1997) Infectivity of Mikrocytos mackini, causative agent of Denman Island disease in Pacific oysters Crassostrea gigas, to various species of oysters. Dis Aquat Org 29:111-116

Brehélin M, Bonami JR, Cousserans F, Vivarès CP (1982) Existence de formes plasmodiales vraies chez Bonamia ostreae parasite de l'huître plate Ostrea edulis. C R Hebd Séances Acad Sci 295:4548

Campalans M, Rojas P, Gonzalez M (2000) Haemocytic parasitosis in the farmed oyster TiTiostrea chilensis. Bull Eur Assoc Fish Pathol 20:31-33

Carnegie RB, Barber BJ, Culloty SC, Figueras AJ, Distel DL (2000) Development of a PCR assay for detection of the oyster pathogen Bonamia ostreae and support for its inclusion in the Haplosporidia. Dis Aquat Org 42:199-206

Chagot D, Boulo V, Hervio D, Mialhe E, Mourton C, Grizel H (1992) Interactions between Bonamia ostreae (Protozoa: Ascetospora) and hemocytes of Ostrea edulis and Crassostrea gigas (Mollusca: Bivalvia): entry mechanisms. J Invertebr Pathol 59:241-249

Cochennec N, Renault T, Boudry P, Chollet B, Gerard A (1998) Bonamia-like parasite found in the Suminoe oyster Crassostrea rivularis reared in France. Dis Aquat Org 34: 193-197

Cochennec N, Le Roux F, Berthe F, Gerard A (2000) Detection of Bonamia ostreae based on small subunit ribosomal probe. J Invertebr Pathol 76:26-32

Comps M, Tigé G, Grizel H (1980) Étude ultrastructurale d'un protiste parasite de l'huître Ostrea edulis L. C R Acad Sci Paris 290:383-384

Dinamani P, Hine PM, Jones JB (1987) Occurrence and characteristics of the haemocyte parasite Bonamia sp. in the New Zealand dredge oyster Tiostrea lutaria. Dis Aquat Org 3:37-44

Elston RA, Farley CA, Kent ML (1986) Occurrence and significance of bonamiasis in European flat oysters Ostrea edulis in North America. Dis Aquat Org 2:49-54

Farley CA, Wolf PH, Elston RA (1988) A long-term study of 'microcell' disease in oysters with a description of new genus Mikrocytos (g.n.), and two new species, Mikrocytos mackini (sp.n.) and Mikrocytos roughleyi (sp. n.). Fish Bull (Wash DC) 86:581-593

Flores BS, Siddall ME, Burreson EM (1996) Phylogeny of the Haplosporidia (Eukaryota: Alveolata) based on small subunit ribosomal RNA gene sequence. J Parasitol 82:616-623
Fong D, Chan MM, Rodriguez R, Chen CC, Liang Y, Littlewood DT, Ford SE (1993) Small subunit ribosomal RNA gene sequence of the parasite protozoan Haplosporidian nelsoni provides a molecular probe for the oyster MSX disease. Mol Biochem Parasitol 62:139-142

Grizel H (1985) Étude des recentes epizooties de l'huître plate Ostrea edulis Linné et de leur impact sur l'ostreiculture Bretonne. PhD thesis, Academie de Montpellier, Université des Sciences et Techniques du Languedoc

Grizel H, Comps M, Raguenes D, Leborgne Y, Tigé G, Martin AG (1983) Bilan des essais d'acclimatation d'Tiostrea chilensis sur les côtes de Bretagne. Rev Trav Inst Pêches marit 46:209-225

Hine PM (1991) Ultrastructural observations on the annual infection pattern of Bonamia sp. in flat oysters, Tiostrea chilensis. Dis Aquat Org 11:163-171

Hine PM (1996) The ecology of Bonamia and decline of bivalve molluscs. NZ J Ecol 20:109-116

Hine PM, Wesney B (1994a) Interaction of phagocytosed Bonamia sp. (Haplosporidia) with haemocytes of oysters (Tiostrea chilensis). Dis Aquat Org 20:219-229

Hine PM, Wesney B (1994b) The functional cytology of Bonamia sp. (Haplosporidia) infecting oysters (Tiostrea chilensis): an ultracytochemical study. Dis Aquat Org 20: 207-217.

Hine PM, Bower SM, Meyer GR, Cochennec-Laureau N, Berthe FCJ (2001a) The ultrastructure of Mikrocytos mackini, the cause of Denman Island disease in oysters Crassostrea spp. and Ostrea spp. in British Columbia, Canada. Dis Aquat Org 45:215-227

Hine PM, Cochennec-Laureau N, Berthe FCJ (2001b). Bonamia exitiosus n. sp. (Haplosporidia) infecting flat oysters Tiostrea chilensis in New Zealand. Dis Aquat Org 47: $63-72$

Kern FG (1993) Shellfish health inspections of Chilean and Australian oysters. J Shellfish Res 12:366

Ko YT, Ford S, Fong D (1995) Characterization of the small subunit ribosomal RNA gene of the oyster parasite Haplosporidium costale. Mol Mar Biol Biotechnol 4:236-240

Le Borgne Y, Le Pennec M (1983) Elevage expérimental de l'huître asiatique Ostrea denselamellosa (Lischke). Vie Mar 5:23-28

McArdle JF, McKiernan F, Foley H, Jones DH (1991) The current status of Bonamia disease in Ireland. Second Meeting on bonamiosis, Ijmuiden. Spe Iss Bonamiosis, Aquaculture 93:273-278

Montes J, Anadon R, Azevedo C (1994) A possible life cycle for Bonamia ostreae on the basis of electron microscopy. J Invertebr Pathol 63:1-6

Nilsen F, Endresen C, Hordvik I (1998) Molecular phylogeny of microsporidians with particular reference to species that infect muscles of fish. J Eukaryot Microbiol 45: $535-543$

Pascual M, Martin AG, Zampatti E, Coatanea D, Defossez J, Robert R (1991) Testing of the Argentina oyster, Ostrea puelchana, in several French oyster farming sites. Int Counc Explor Sea Comm Meet (Shellfish, Benthos Comm) K: 26 Sept-4 Oct 1991

Pichot Y, Comps M, Tigé G, Grizel H, Rabouin MA (1980) Recherches sur Bonamia ostreae gen. n., sp. n., parasite nouveau de l'huître plate Ostrea edulis. Rev Trav Inst Pêches Marit 43:131-140

Polanco E, Montes J, Outon MJ, Melendez MI (1984) Situation pathologique du stock d'huîtres plates en Galice en relation avec Bonamia ostreae. Haliotis 14:91-95

Quayle DB (1961) Denman Island oyster disease and mortality, 1960. Fish Res Board Can Manuscr Rep Ser 713:1-9 
Roughley T (1926) An investigation of the cause of an oyster mortality on the Georges River, New South Wales, 1924-25. Proc Linn Soc NSW 51:446-491

Sambrook J, Fritsch EF, Maniatis T (1989) Molecular cloning: a laboratory manual. Cold Spring Harbor Laboratory Press, Cold Spring Harbor, NY

Stokes NA, Siddall ME, Burreson EM (1995) Small subunit ribosomal RNA gene sequence of Minchinia teredinis (Haplosporidia: Haplosporidiidae) and a specific DNA probe and

Editorial responsibility: Albert Sparks,

Seattle, Washington, USA
PCR primers for its detection. J Invertebr Pathol 65:300-308 Swofford DL (2002) PAUP*. Phylogenetic analysis using parsimony ( ${ }^{*}$ and other methods): version 4 . Sinauer Associates, Sunderland, MA

Thompson JD, Higgins DG, Gibson TJ (1994) CLUSTAL W: improving the sensitivity of progressive multiple sequence alignment through sequence weighting, position-specific gap penalties and weight matrix choice. Nucleic Acids Res 22:4673-4680

Submitted: May 21, 2002; Accepted: October 21, 2002 Proofs received from author(s): April 10, 2003 